\section{BOOKS: THE WAREHOUSE OF KNOWLEDGE}

$\mathrm{T}$ HE technical agencies in education and in the dissemination of knowledge are growing in kind and variety. In our basic seminaries-the schoolswe have the teacher in the class and lecture rooms, the experimental laboratory, the workshop and garden, the cinema, the radio, and so forth. These are immediatly effective; but very seldom may the pupil refer back to them when and where he will.

In this respect the text-book differs from all these. Although the film, for example, can cescribe and illustrate, especially scientific phenomena, in such a way that no text-book could emulate, nothing but the book can claim the quality of permanence or give the enthusiastic pupil that pride of possession which is an essential need to the immediate aim of acquisition of knowledge and the ultimate aim of a good education. The pupil can refer back time and again to his books, he can read and re-read until he has digested all those books have to offer.

Furthermore, books and journals are practically the only means whereby an individual person is able to keep a record of the progress of knowledge. Nature itself, for example, is not only a forum for scientific discussion and a newspaper for men of science, but it also aims at building up a printed and therefore a permanent record of scientific progress and discovery, so that an issue of Nature of thirty years ago is in certain respects as valuable as this week's issue. This cannot be said of any other of the above. mentioned agents of education, in so far as any one individual person is concerned, since so few can hope to make a library of films.

Books and journals, therefore, must for a very long time continue to hold a unique position both in general education and technical training.

Unfortunately, unless help is quickly forthcoming, we shall soon find that the supply of books for all purposes, including general education, scientific advancement and research, medicine and so on, will be totally inadequate to meet even essential requirements.

A brief review of the present position carries this conviction.

The last year of peace was bad. We were living in suspense, and even education authorities were making do with books in hand rather than make their normal annual purchases. Publishers themselves restricted their activities because of the threat of war.

Thus, book production for 1938-39 was small, but the paper now allocated to publishers for books amounts to 40 per cent of their 1938-39 consumption -and a recent ruling of the Paper Control has made it impossible for publishers even to obtain their full quota.

Certain agreed restrictions such as thin paper, small page margins and small type have enabled such books as the ordinary novel to be produced on very much less paper per book, but other types, such as school books, were already produced on a strictly economical basis. Accordingly, the numbers of school and university texts, etc., that can be produced has probably been cut by something like 50 per cent throughout the period of the War.

In 1939 publishers carried good stocks of books and paper; but this reserve of paper has now been used, and the stock of books is rapidly decreasing.

Figures collected by the Publishers' Association from representative publishers show the following result :

\begin{tabular}{|c|c|c|c|}
\hline $\begin{array}{l}\text { Stocks at end of } 1942 \\
\text { Printed during } 1943\end{array}$ & $\begin{array}{l}\cdots \\
\cdots\end{array}$ & $\begin{array}{l}\cdots \\
\cdots\end{array}$ & $\begin{array}{c}\text { Books } \\
33,136,254 \\
12,184,277\end{array}$ \\
\hline Sales during $1943 \ldots$ & . & . & $\begin{array}{r}45,320,531 \\
18,146,471\end{array}$ \\
\hline Stock at end of 1943 & . & .. & $27,174,060$ \\
\hline
\end{tabular}

With pre-war stocks of paper gone, the production for 1944 can reasonably be put at $10,000,000$ books only. The sales for the year, though really governed by supplies, could not be put at less than 25 per cent up on 1943. This would give us the following position :

\begin{tabular}{ll} 
Stock at end of 1943 & $\ldots$ \\
Estimated printed during 1944, say & $\begin{array}{l}27,174,060 \\
10,000,000\end{array}$ \\
\hline Estimated sales during 1944 , say & $\begin{array}{r}37,174,060 \\
22,674,060\end{array}$ \\
\hline Estimated stock at end of 1944, say & $? 4,500,000$
\end{tabular}

Thus one more year will put the publishing of books, etc., on a real hand-to-mouth basis.

It must also be remembered that much of the stock shown in the above figures are still pre-war books in slow but constant demand-many of them are important books of their type, but they are not books that are in urgent and immediate demand. Accordingly, it is quite likely that some $10,000,000$ of the stocks shown above should be deleted altogether from consideration of books available for immediate urgent necessity.

But the consumption tends to increase not merely rapidly but alarmingly. Schools that have made do for several years now wish to return to efficiency again. An enormous scheme is on foot for Army post-war education. And so it goes on. For home and export, books of all sorts are vociferously demanded.

What is the publisher to do ? The demand is for all types of books-one type cannot be sacrificed to help another. Orders pour in.

The publisher is practically driven to printing small editions. This is a most uneconomic proceeding and entails increased prices to the public. An even worse effect is the additional work per book thrown on to printers and binders. Making ready, as it is called, is a very lengthy process and these short runs materially reduce both binders' and printers' output.

So we arrive at the state when even an increase of paper will not immediately ease the situation. It will take time to get back to longer runs, and it is vitally urgent that this return to economic methods of production be initiated forthwith.

Incidentally, publishers may be almost entirely 
absolved of pressing for financial gain. Excess Profits Tax sees to that, and larger sales will only swell the Government's receipts - not the publisher's.

Printers and binders have, of course, been denuded of labour. Notwithstanding early official statements that books were necessary to the prosecution of the War, the book trade has been largely unprotected, and surely the time has now come to give the trade a chance to turn out the millions of books that are admittedly essentially required.

As mentioned above, demands are being received for books for Army education. Extra paper is promised for these, but printers and binders are not able to deal with additional work. As pointed out, a general increase in paper supplies would tend to ease the situation, but it is not possible to impose further demands on printers and binders whilst they are handling the present multitude of short runs.

However, the offer proves additional paper is available, as indeed do long-established cases of books produced of a popular technical nature for which paper has been made available by one or other of the Services. We do not know who has the authority to say which books are sufficiently valuable to the Services to merit Government paper, but we question his decision in many cases.

However, the Government has plenty of paper at its disposal, as indeed H.M. Stationery Office must now rank high as regards the quantity of its publications. Is this continuous stream of Governmentbacked but apparently unofficial pamphlets and booklets of greater value than the type of books which have been in demand for many years? Who has decided that this is the best use for paper in wartime?

The current consumption figures for paper as follows are of considerable interest :

\begin{tabular}{|c|c|c|}
\hline & & Tons \\
\hline Newspapers & . & 250,000 \\
\hline H.M. Stationery Office & ・ & 100,000 \\
\hline Periodicals & ...(nearly) & 50,000 \\
\hline War Office (included in & H.M.S.O. & \\
\hline quota) & - & 25,000 \\
\hline Books (including the extra & $\left.2 \frac{1}{2} \%\right) \quad \ldots$ & 22,000 \\
\hline
\end{tabular}

American Book Publishers' quota for 1943 was $\quad \ldots \quad$. .

128,000

Presumably much of the War Department paper went on training booklets and the like. Surely training has now decreased to some extent, so that the publishers could have some or all of the now redundant paper. What about the Civil Defence Services? Surely these are organized now and could reduce their requirements for paper. And so with other Government Departments. At the same time, this reduction of H.M. Stationery Office paper consumption would reduce their compulsory orders to printers and binders. This would further help to square out the vicious circle now fettering the book trade.

For four years, educationists and men of science have valiantly shouldered the heavy burdens imposed by the short supply of essential literature in the form of text-books and technical journals. But surely science can claim war-time priority; furthermore, war or no war, progress in education must not be allowed to stop altogether, though it must, of course, pro tem. reduce its pace.

At present, of the 420,000 tons of paper in the country available for printing, only little more than 5 per cent is allowed for books-and this comprises books of all kinds, including those which with no stretch of the imagination can claim to have literary or educational merit. This position can and should be adjusted if educationists and men of science are to be encouraged to give of their best-and their roles at the present time, and even in the more difficult years of peace-making and reconstruction to follow, are of the highest importance. Readjustment can be made fairly simply by modifying the percentage of quotas.

\section{INDUSTRIAL TOXICOLOGY}

\section{Industrial Toxicology}

Being the Croonian Lectures for 1942 of the Royal College of Physicians of London. By Dr. Donald Hunter. Pp. 80. (Oxford: Clarendon Press; London: Oxford University Press, 1944.) 10s. net.

A NY review of the present field of industrial A toxicology necessarily suffers from the fact that it is more or less an 'interim' report, issued during a period when comparatively little has been added to the pre-war knowledge of existing toxic substances, and before the expected development of many new agents which may or may not prove injurious to workers exposed to them.

It is well that existing knowledge should be brought up to date, both from the biological as well as the purely chemical and physical aspect.

The latter is specially emphasized in Dr. Donald Hunter's review of a large number of toxie substances encountered in industry. Immunity from danger in handling many substances essential to industry both in war and peace depends to a large extent on accurate recognition of the chemical and physical properties of those already known to be toxic. Such knowledge can be usefully applied in forecasting the probable potential toxicity of new substances the harmful effects of which have not yet been emphasized. by the results of bitter practical experience.

In Dr. Hunter's review, the relationship of chemical constitution and physical properties to biological activity is shown by many examples in the various groups of metals, aromatic compounds and chlorinated hydrocarbons. A typical difference in effect of the same element in different chemical combinations is the contrast between the manifestations of poisoning by inorganic lead, where true lead encephalopathy is now rarely seen, and the cerebral disturbance, sometimes terminating in violent mania, which is the outstanding phenomenon in poisoning by the organic compound, tetra-ethyl lead, and is unaccompanied by the classical symptoms of lead colic, palsy or punctate basophilia. The picture of severe chronic benzene poisoning, with the most frequent effect of aplasia of the bone-marrow, is also quite distinct from the specific capacity of the nitro- and aminoderivatives of benzene to convert hæmoglobin into methrmoglobin, and the special tendency of the amino-derivatives to attack the bladder, causing papillomata which may become malignant. 